\title{
LEX UBER. OBLIGATIONS OF THE INTERMEDIARY AND DRIVER IN NEW ROAD TRANSPORT REGULATIONS
}

\author{
Szymon RUBISZ \\ Silesian University of Technology, Faculty of Organization and Management, Zabrze; szymon.rubisz@polsl.pl, \\ ORCID: 0000-0002-0999-5855
}

Purpose: The purpose of the article is to discuss and analyze new regulations regarding passenger transport, new obligations of intermediaries such as Uber and drivers using such platforms.

Design/methodology/approach: Analysis and interpretation of legal provisions, analysis of the socio-economic context and desirable implications.

Findings: The new regulations should increase the sense of justice and equal treatment of entrepreneurs due to the unification of the requirements for all entities providing passenger transport services. Potential increase in the quality of transport services for consumers due to greater legal certainty and standards. Regulating the status and activities of intermediary platforms that have previously operated in the sphere of legal uncertainty.

Originality/value: This is one of the few first studies on regulations that have been in force recently and regulating the controversy related to Uber's activity in Poland. This should be a practical source of knowledge and conclusions about the applicable regulations for transport companies, drivers wishing to operate e.g. under the Uber banner, as well as aware passengers who can expect the quality of services provided.

Keywords: Uber, road transport, licensing obligations, sharing economy, taxi.

Category of the paper: Research paper.

\section{Introduction}

The amended Act on road transport has been in force since the beginning of 2020 (Dz.U. z 2019 poz. 2140). Changes in the law, especially in terms of requirements for the transport of passengers, were long awaited (cf. Rozwadowska, 2017) thanks to the American company Uber operating on the Polish market since 2014. It offers an internet platform in the form of a mobile application, mediating contact between independent car drivers and people who want to take advantage of paid travel. The application itself calculates the due fee and collects it from the account of the registered customer, and after deducting its commission, 
transfers funds to the driver. This innovative solution quickly gained many supporters according to research in mid-2018, nearly 60 percent of Poles looking for transport used this type of service (Duszczyk, 2018).

Uber's activity has been a source of controversy for years, not only in Poland ${ }^{1}$. It is because the passenger transport market, above all taxi services, has entered a dangerous - as it turned out - competitor, competing for the same customer, but offering greater convenience and modernity of use. Its functioning, however, took place in the sphere of legal uncertainty, because the regulations did not provide for the existence of this type of intermediary, his activities were not subject to regulation, and the scope of responsibility was limited to those related to the offered application. Drivers using the platform and their vehicles did not have to meet strict requirements such as taxis, often they did not have the appropriate license, despite the existence of such an obligation. Administrative barriers and entry costs were therefore much less severe.

The operation of the Uber and similar platforms is therefore an interesting social, economic and legal problem. These enterprises arouse huge negative emotions and even hostile attitudes of entities whose existence on the market is regulated in detail. Finally, the industry's strong reaction forced the legislator to act, resulting in the aforementioned amendment to the Road Transport Act. It is worth emphasizing that the new law aims to equalize opportunities in the market game by fostering fair competition, and at the same time takes into account and legalizes innovative technological solutions in the sphere of traditionally provided services.

The purpose of this study is to analyze the legal provisions of the platform and the drivers cooperating with it, based on the Act on road transport both its provisions before the amendment and those currently in force since the beginning of 2020. However, the discussion and interpretation of regulations must be preceded by outlining the economic and social context, after all, the legislator's intentions do not function in isolation from existing phenomena and related needs. Therefore, the first part of the work describes the business model adopted by Uber and the so-called sharing economics - the broader concept it comes from. The example of this particular enterprise is symbolic here, because in the media circulation the new regulations on road transport have gained a name „Lex Uber”.

\footnotetext{
${ }^{1}$ Uber was outlawed by the Supreme Court in Bulgaria in 2015 after a 50,000 euri fine was imposed on the tax and transport administration. Changes to the law that prevented its activity took place, among others, in Denmark, Hungary, some states of the USA and the Northern Territory in Australia. The service has been partially blocked in many cities in Germany, France, Finland, the Netherlands and Italy (Dickinson, 2018). Faced with huge financial losses, Uber also withdrew from China and its branch was bought by a competing company (Rhodes, 2017).
} 


\section{Sharing economy}

For several years, the phenomenon of sharing economy has become increasingly popular in scientific literature and, consequently, in journalism. Its socio-economic, legal and technological aspects have found expression in many studies. Most often they are defined as an economic system based on sharing by people not fully used resources or services, for a fee or free of charge. It is important here that this "sharing" takes place between natural persons, partly or completely outside the traditional, highly institutionalized system of economic exchange (cf. Botsman, 2015). In this new, alternative economy, exchange as sharing is possible only in the conditions of development of new technologies, therefore, when explaining the concept in question, one should refer to online activity (cf. Belk, 2014, p. 1596). J. Hamari, M. Sjoklint and A. Ukkonen $(2015$, p. 5) therefore propose considering the economy of sharing as a p2p-based activity of obtaining or sharing access to goods and services coordinated by online social services.

This phenomenon is not something new, because it has always existed in interpersonal relations. The desire to cooperate, share ones resources and tools enabling them to be used with others, neighborly help, etc., were typical behaviors within clans and small communities. Thanks to this, people had access to private goods or skills that they did not have, but which could be borrowed or rented from others, by repaying in a similar, material or immaterial way. Nowadays, due to the dynamic development of the Internet and a significant increase in the availability of its services, the idea of sharing has ceased to be local. The circle of people who potentially could benefit from a much richer offer of various possibilities has expanded. Collaboration does not have to take place among relatives and friends - it is also open to others, the novelty is sharing with strangers (Schor, 2014). The popularity of the trend is mainly due to the consumer's conscious assumption that he does not have to be the owner of a specific good, which he anyway would only use occasionally, because there are other people who own it and are willing to share it in exchange for a fixed fee (cf. Rudnicka). By concluding such a contract, one can feel satisfaction due to the lower cost of meeting a temporary need. The other party to the transaction, however, has the option of unlocking the value of the unused good or the underused asset (Burgiel, 2015, p. 153). Additionally to this there is a key economic goal, i.e. it is not a culture of gifts, but a way to earn money (Sundararajan, 2016, p. 5-6).

The idea of sharing implemented thanks to the Internet quite quickly became an inspiration for completely new business models, under which enterprises took care of intermediation between entities willing to establish such a contractual relationship. This covered very different sectors of the economy, including e.g. tourism (rental of local guides), hotel industry (accommodation in private homes), real estate (short-term rental) and transport (vehicle sharing). Intermediation is usually carried out using a dedicated network platform (computer program) made available as a mobile application, thanks to which, after meeting certain criteria, 
people who want to share a given good are associated and contacted. They are responsible for the performance of the contract, and the intermediary charges a commission for this ${ }^{2}$.

In view of the above, it is not difficult to guess that the above-mentioned business models are often a source of conflict of interest with traditional service providers already existing on the market. Professional companies offering hotel or transport services gain significant competition, which operates in a modern way, directly reaching the customer, generating lower operating costs due to, for example, the lack of the need to employ qualified personnel or obtaining appropriate licenses and permits. Of these reasons, among others, traditional companies oppose such new players by accusing them of unfair business practices, circumvention of laws, and even outright activities (cf. Toron, and Wiese, 2017, p. 13-14).

\section{Uber as a business model}

In recent years, the casus of the American company $\mathrm{Uber}^{3}$ has grown to the rank of symbol of this battle. It creates a kind of international transport network, under which, one of the key services provided in many cities of the world is brokering in shared passenger transport (cf. Stępnicka, 2018, p. 490). Thanks to the mobile application offered by Uber, you can order a car transport service, and the driver and passenger are associated by the algorithm in simplification - taking into account their locations determined by GPS coordinates. Drivers registered in the Uber service on the application screen can see the trip ordered nearby and the route to be implemented, and after they are accepted, they can contact the customer directly to arrange a meeting and perform the service. In turn, the consumer may accept or reject the driver after getting acquainted with the type of vehicle and opinions issued by other passengers. The course fee is estimated based on the actual route length and travel time based on GPS devices on users' smartphones. It is downloaded not by the driver but by the intermediary from the credit card registered in the passenger's application and, after deducting the commission, transferred to the driver's account. Therefore, neither the driver nor the customer negotiate the terms of payment for transport, because these are imposed in advance by Uber, and the settlement takes place as if without the direct participation of the actual parties to the contract. This can be seen as an advantage of the service due to the lack of having to carry cash or another payment tool. In addition, when ordering the course, the customer immediately learns how

\footnotetext{
${ }^{2}$ However, the role of a professional intermediary does not have to be limited to enabling contact and collecting commissions. Intermediation also concerns the transfer of money to an entity sharing the good, its certification or authorization, responding to complaints of users, etc.

${ }^{3}$ It is certainly symbolic that the "uberization" refers to changes in various industries in which business models use modern digital technologies to minimize the distance between the service provider and recipient, and its quality is subject to public follow-up assessment by the consumer (Pichère, 2016).
} 
much he will pay for it, and any increase in this amount will depend on road conditions or unexpected extension of the journey time (more broadly Toron, and Wiese, 2017, p. 12).

The above description clearly shows that the profile of activity in question is a significant competition for traditional entrepreneurs engaged in passenger transport, and above all for taxi corporations. He shares two of the most important similarity features with them, i.e. the same business purpose and actually the same circle of service recipients. Also from the passenger's point of view, the service offered by these entities, both Uber and professional carriers, generally satisfies the same need in the same way. The main difference boils down to greater comfort and modernity in the case of the former, and often also a lower fee. Therefore, the choice of an aware consumer seems obvious, although it must also be admitted that it does not have to be the rule. For some consumers, the license, which certainly has a taxi driver or a professional corporation, can give a sense of guarantee of the quality of the service provided, and thus, above all, preparation of the driver in terms of knowledge of the given city, control of his health predispositions to practice the profession and the proper technical condition of the vehicle.

Ensuring compliance with these conditions requires significant expenditure from taxi companies. It is not surprising, therefore, that they are strongly opposed to the growing competitor, who easily wins the market by attracting customers with modern solutions and sometimes more attractive prices, while acting in the sphere of legal uncertainty as to the need to fulfill the obligations set out in legal regulations (Duszczenko, 2019). This opposition led to the fact that in some countries this service was completely or partially outlawed or suspended, while in many others the legislator had to focus on the problem. It turned out that national legal systems are not adapted to the business model in question.

\section{Legal status of Uber in the European Union}

It is obvious that since the type of specific economic activity raises a lot of controversy and encounters a number of interpretation doubts in the member states of the European Union, it must become the subject of interest of its bodies. According to European Commission, the generally understood sharing economy is a new opportunity for entrepreneurs and consumers that can translate into economic growth and job creation in the EU, provided that it is responsibly supported and developed. Building market models based on this idea is therefore desirable, although of course there is no lack of legal uncertainty associated with business entities, consumers and sometimes even public authorities.

The EC in its 2016 communication (European Commission, 2016) states that the entity providing services in the so-called sharing economy may be required to have an appropriate license, permission to operate or must meet the minimum requirements regarding quality 
standards only if "This is necessary from the point of view of the public interest". The ban on such activities should only be the final solution. However, the Commission pays special attention to the so-called cooperation platforms, in other words those whose role is to associate entities offering the service and entities seeking it (such as Uber but also Airbnb ${ }^{4}$, BlaBlaCar ${ }^{5}$, etc.). It is stated that if they provide "a service normally provided for remuneration, at a distance, by electronic means and at the individual request of a recipient" (art. 2 (a) and of the 2000/31/EC directive) it is an information society service and, according to EU law, it is not covered by a prior authorization or similar requirement specifically and solely in relation to it. However, if the platform, apart from the above, provides other basic services (e.g. transport, short-term rental), then it may be subject to relevant sectoral regulations, including mandatory business permits or licenses.

According to the EC, whether a given platform provides basic services at the same time can be assessed in terms of its relations with suppliers (e.g. drivers using the Uber application), i.e. the degree of control over them or influence. When determining them, one should first use the criterion of remuneration conditions, i.e. whether the final price for the service is imposed in advance by the platform and charged to the consumer, or whether the supplier is free to adjust this price to the level recommended by the intermediary. Secondly, are contractual terms other than the price agreed between the supplier and the consumer, e.g. an obligation to provide the service, determined by the intermediary. Finally, whether the collaboration platform owns the key resources used to provide the service, i.e. vehicles, premises, tools, etc. The combined fulfillment of these three criteria, according to the EC, leads to the conclusion that the platform, in addition to the information society service, also provides a basic service, so as such it may be subject to the obligation to obtain a sectoral business authorization or license (European Commission, 2016, pp. 6-7). Given the above, in the light of the interpretation of EU law by the European Commission, such an obligation should not be imposed on the Uber platform.

Member States, in line with the Commission's further reasoning, should ensure that professional service providers are distinguished from private service providers occasionally sharing their resources or providing the service. For example, thresholds that take into account the level of income generated or the regularity of service provision would be helpful here. If they are not exceeded, service providers may be subject to less strict requirements. According to the EC both cooperation platforms and people providing services through them should be subject to tax liability on an equal footing with other market participants, i.e. pay income taxes or VAT.

This document also discusses, among others, the issue of possible liability of cooperation platforms. Under EU law, providers of information society services as intermediaries are exempted from liability for stored information under certain conditions. This is the case when

\footnotetext{
${ }^{4}$ A platform that associates people offering and looking for short-term accommodation.

${ }^{5}$ Ridesharing service connecting drivers who have free places in their cars with passengers traveling in the same direction over a long distance.
} 
the provider does not take actions that would give him knowledge of unlawfully stored information, and has no awareness or control over it, as well as when, upon obtaining such knowledge or awareness, he acts expeditiously to remove it or to disable access to it (art. 14 of the $2000 / 31 /$ EC directive $^{6}$ ). A kind of data hosting, which is only used to place service announcements and enable contact between the supplier and the consumer, if it is purely technical, passive and automatic, seems to meet the directive's criterion regarding the exclusion of liability (European Commission, 2016, p. 8-9). Therefore, in the case of the Uber platform, there can be no liability for the services provided by drivers, as these are not the subject of the company's business. However, there is certainly responsibility for the services it provides, e.g. related to payment collection, technical efficiency of the application, a tool used to give opinions and assess users, etc. This, of course, does not mean that the consumer is deprived of any protection when using the transport service, because this, as emphasized by the EC, must be guaranteed by national legislation. The addressee of any claims should, however, be the entity actually responsible for the transport, and not the intermediary associating the parties to the contract. His role could certainly boil down to being a valuable source of information if claims had to be proved.

The above guidelines issued by the European Commission, although based on the interpretation of applicable EU law, are not binding on Member States. The EU has not yet adopted any specific regulations in this area, which is why in 2017 the European Parliament adopted a resolution calling on the EC to create comprehensive regulations on the sharing economy. It is noted that the issues identified in the Commission statement should be reflected in a normative act (European Parliament, 2017). The new regulations must ensure a level playing field for all entrepreneurs, but they should not restrict or hinder the provision of services. The sharing economy is not a threat to the traditional one, but it is socially beneficial to EU citizens (Kiwnik-Pargana, 2017).

In the case of Uber, the Court of Justice of the European Union finally took the floor in judgment in Case C-434/15. The Spanish court, when examining the claim of an organization of taxi drivers from Barcelona against the Spanish branch of Uber for unfair competition, asked a question for a preliminary ruling to the CJEU whether Uber provides transport services, information society services or a combination thereof under EU law. The possibility to impose the obligation to obtain the relevant administrative permit depended on the qualifications. The Court has explicitly stated that Uber's activity is not limited to intermediating between drivers and customers, but it provides individual urban transport services, which it provides in particular through IT tools such as an application. The company's comprehensive service consists of several elements, including intermediation, but the transport service is the main one, because the transport conditions and the rules that the driver must follow are imposed by the intermediary. Therefore, Uber's activities should be regarded as providing 'transport services'

\footnotetext{
${ }^{6}$ Similarly, also art. 14 of the Polish Act on the provision of electronic services (Dz.U. 2019, poz. 123).
} 
and not 'information society services'. It is therefore excluded from the general freedom to provide services and as such should be regulated by Member States in the field of transport, such as for example taxi companies.

Although the judgment of the CJEU is not an universally binding EU law, it is of great importance for its interpretation by the Member States and Community bodies. The theses of the judgment show a more restrictive interpretation of EU legislation than was the case in the EC statement. However, thanks to this, national legislation has an open way to harmonize regulations and ensure the principles of fair and equal competition in the passenger transport industry.

\section{Legal status of Uber in Poland before "Lex Uber"}

As previously stated, the service, symbolized by Uber and similar enterprises, has significant similarities with the passenger transport industry, especially the taxi service. However, it should be emphasized that from the legal point of view, differences exist and are of great importance for this market. The taxi is "a car vehicle, properly equipped and marked, intended for transporting no more than 9 persons including the driver and their hand luggage for a fee determined on the basis of a taximeter". The cited regulation sets out the definition of a taxi while paying attention to the appropriate marking of the vehicle, i.e. additional white or yellow light with the inscription "TAXI" on the roof, as well as the need for a taximeter a special measuring instrument for calculating tolls according to set tariffs. It is worth adding that it must be legalized by the office of measurement or an authorized company, and this operation should be repeated every 25 months. In addition, the device should work with the cash register in such a way that uninterrupted data transmission between them is possible. Additional conditions that must be met by a vehicle used as a taxi include at least two places for passengers, room for hand luggage of the passenger, a spare tire. It must also undergo extended technical tests related to its function annually.

In addition to technical requirements, the taxi must also comply with the formal ones, which in turn are regulated by the Act on road transport. According to art. 5b (1)(3) taking and carrying passengers by taxi requires obtaining the appropriate license. It is temporary and, taking into account the application of the party, cannot be issued for a period shorter than 2 years and longer than 50 years. Applicants must have a certificate of no criminal record and no prohibition to carry out economic activities in the field of road transport (art. 5c (1)(1)). It is also necessary to have a legal title to dispose of a vehicle that meets the previously described technical requirements (art. 5c (1)(5)). In addition, the driver must meet other conditions specified in art. 39a (1) (1-4): be at least one year old (depending on the driving license category), 
have appropriate driving licenses, certificate of absence of health and psychological contraindications to work as a driver.

The license is granted by the commune head, mayor or city president for a specific vehicle and area covering the municipality, neighboring municipalities (in the case of an intermunicipal agreement), and in the case of Warsaw, for the entire capital city. It is also worth mentioning that based on art. $11 \mathrm{~b}$ of the Act, the commune council may set maximum prices for taxi transport and specify the applicable price zones (maximum tariff rates) for the transport of passengers and cargo.

While the regulations apply to taxi activities in quite detail, Uber, as already mentioned, escaped legal regulations. As an online platform, it mediates contact between a transport entrepreneur ${ }^{7}$ - driver and a customer, and is not an entity providing taxi or other services involving the transport of passengers. It is also not formally a corporation employing employees providing such services on its behalf. In the opinion of the Office of Competition and Consumer Protection in 2016, the role of Uber is limited to providing and operating an electronic platform enabling contact between the driver and the customer and making payments. This service is therefore similar to those provided by other intermediaries, such as "platforms enabling hotel booking, renting a private apartment or making purchases from individual sellers" (UOKiK, 2016). Therefore, it cannot be argued that the company in question infringes legal order by its activities; no legal act in force prohibits it.

The previous provisions of act on road transport did not provide for the existence of an intermediary such as Uber, although the rules certainly applied to drivers using the platform. They in fact carry out real activity consisting in the transport of persons, which is regulated by the said Act. Therefore, the same obligation as for taxi drivers rested on them with the obligation to obtain a license, however, for the carriage of passengers by car (art. 5b (1)(1)) or a car designed to carry 7-9 people in total with the driver (art. 5b (1)(2)). Also in these cases, the legislator required the applicant to meet the same conditions as for taxi drivers. In addition, however, the driver should have had a certificate of professional competence confirming his qualifications and knowledge necessary to take up and pursue economic activity in the field of road transport.

The obligation to have a license for drivers using Uber has also been confirmed in case law. For example, the Voivodship Administrative Court in Olsztyn in a judgment of 2018 (II SA/O1 977/17) ruled that "the obligation to have a license authorizing road transport applies to entities actually carrying out activities that meet the definition of road transport" regardless of whether the activity has been reported as an object of economic activity. Similarly, in 2018, the Voivodship Administrative Court in Łódź (III SA / Łd 686/17) recognized the legitimacy of a fine imposed on the driver in the amount of 10,000 PLN for violation of the provisions of

\footnotetext{
${ }^{7}$ Due to the fact that such activity is organized and continuous, and its purpose is for profit, it exhausts the premises for the definition of economic activity expressed in art. 3 Rights of entrepreneurs (Dz. U. 2018 poz. 646). The driver must register it with CEIDG register before he starts providing services.
} 
the Act on road transport, including for lack of the required license. These rulings were the result of administrative proceedings in cases where drivers did not recognize fines imposed on them in inspections carried out by authorized bodies (more Stalmach, 2014; Słowik and Styczyński, 2016; Szanduła, 2016).

In addition to the above, there was another problem related to the legality of passenger transport by unprofessional drivers using the Uber platform, which resulted from the interpretation of regulations and the cited case law. The services they provide are so-called occasional transport, i.e. not regular transport, special regular transport or a shuttle transport (art. 4 (11)). The previously cited ruling of the Voivodship Administrative Court in Lódź (III SA/Łd 686/17) drew attention to the imprecision of the statutory definition, therefore one should use the criteria characterizing occasional transport in EU regulations. The provision of art. 2 (4) of Regulation 1073/2009 (OJ L 300) indicates that the main feature of occasional services is that they include the transport of groups of passengers formed on the initiative of the customer or the carrier himself. The court therefore concluded that "unlike regular transport, occasional passenger transport involves the provision of passenger transport services on occurring occasions initiated by the customer or the carrier". It also follows that this should be understood as such a transport that is not carried out at specific intervals and on certain routes. This classification of Uber drivers' services means that they must meet the additional requirements of Art. 18 of the Act on road transport: occasional transport is carried out with a motor vehicle designed for the transport of more than 7 people, including the driver (art. $18(4 a))$.

As it results from the above analysis, the provisions of the Act, which were in force until the end of 2019, significantly limited the driver wanting to legally provide passenger transport services by car using the Uber application. The mechanism of the platform made it impossible to meet all the criteria for the occasional carriage of passengers, as set out in art. 18 (4b). This excluded the sense of applying for a license to transport people by car and the only thing left was to provide the service with a car structurally adapted to transport at least 7 people with the driver (art. 18 (4a)) and therefore obtain the appropriate license. In turn, the taxi license is associated with compliance with all statutory requirements for the appropriate vehicle marking, equipment (e.g. taximeter) and mandatory inspections, and therefore excluded.

Meanwhile, Uber did not require the cooperating driver to submit documents confirming compliance with the above requirements, including above all licenses. To use the application as a passenger transport service, it was enough to show an identity card confirming the age of 20 or more, driving license valid for at least one year, a certificate from criminal record, confirmation of business activity or connecting to a partner with a license for domestic transport of people by car, and portrait photos (Uber, 2019). Such company policy certainly does not help build a positive image. 


\section{Lex Uber - new rules on road transport}

In mid-2019, after several years of work, an amendment to the Road Transport Act was adopted. The new regulations came into force on January 1,2020, and their purpose is precisely to respond to phenomena such as Uber.

Economic activity in the field of intermediation in passenger transport was covered by the notion of road transport as defined in art. 4 point 3 . The intermediation itself, however, consists in forwarding orders for the carriage of persons by car, a vehicle designed for the transport of more than 7 and not more than 9 persons including the driver (hereinafter a 7-9 passenger vehicle) or a taxi. In addition, the conclusion of the contract of carriage on behalf of the client or entrepreneur performing the transport, charging a transport fee, or enabling the conclusion of a contract of carriage or enabling settlement of the charge for the carriage of these vehicles can take place via electronic means of communication, internet domains, mobile applications, computer programs, ICT systems or other means of communication.

The above legal definition implies taking into account the functioning of such business models on the market as Uber and similar platforms contacting drivers and customers. Recognition in the regulations of this type of business activity is a response to problems related to competitiveness on the transport market. Uniform requirements and legal conditions are introduced for companies that provide intermediation in contact between drivers providing passenger transport services and customers. This move therefore seems right and desirable. The use of modern technologies, primarily mobile applications, for ordering transport or settling the fees due for it should also be definitely rated positively. This corresponds to modern trends in many market sectors, and certainly adapts the regulations to the needs and expectations of consumers of such services.

The introduction of rules conducive to fair competition and equal opportunities was not the only goal of the amendment. It also ensures more effective administrative control of the functioning of contacting platforms and entities cooperating with them. Defining the activities of the intermediary in the transport of passengers is intended to introduce its regulation. According to the provision of art. $5 \mathrm{~b}$ paragraph 2, undertaking and performing road transport in the field of intermediation in passenger transport requires an appropriate license. The intermediary ${ }^{8}$, according to art. 5 (2a), may obtain it provided that there is no final conviction for criminal fiscal or other intentional offenses against security in communication, property, economic turnover, document credibility, the environment or working and pay conditions, or other matters related to the profession, and proof that there has been no final judgment issued prohibiting business activities in the field of road transport (art. 5c (1) (1)). In addition, the applicant for a license should be in a financial position ensuring the

\footnotetext{
${ }^{8}$ More specifically, members of the management body of a legal person, persons managing a general partnership or a limited partnership, and in the case of another entrepreneur - persons conducting business activity.
} 
establishment and pursuit of economic activity in the field of road transport as determined by available financial means or assets in the amount of 5,000 PLN, and also be an entrepreneur registered in CEIDG or KRS.

The Chief Road Transport Inspector is to deal with granting, refusing, changing or withdrawing a license for an intermediary in the carriage of persons (art. 7 (4) (4)). On the basis of art. 27d, this body maintains, available in the Public Information Bulletin, a list of companies involved in the provision of intermediation in the transport of persons, containing information necessary for their identification (i.e. company name, address and name of the seat or place of business, information about the entry in the CEIDG register or number in KRS register and license number). Thanks to these changes, it will be more effective to control the correctness of this type of business activity conducted by intermediaries and cooperating entities. Drivers and consumers, on the other hand, will be sure about the legality of the platform they want to use. This is important especially for the former, since the new art. $27 \mathrm{c}$ forbade the driver to perform road transport on the basis of the order he obtained thanks to an intermediary without a license to transport passengers.

Another significant regulation is the limitation of intermediary services only to drivers who have a license to transport a car, a 7-9 passenger vehicle or a taxi (art. 5d). If the intermediary does not comply with this restriction, he is threatened with a fine ${ }^{9}$ and initiating the procedure of withdrawal of the license pursuant to art. 15 (1)(5). Art. 5e also stipulates that brokering persons in occasional transport may not apply to motor vehicles structurally designed for the carriage of no more than 7 people together with a driver. Thus, it limits the scope of services provided by intermediaries to order journeys only with vehicles registered for more than 7 people or taxis.

It should be recalled that, in the light of regulations and case-law, the transport of persons which takes place in the case of services provided through Uber is actually an occasional transport. It is not a taxi or the more so transport of people of a regular, regular special or shuttle character, i.e. other types of transport provided for by the Act. The regulation of art. 18 (4a) stipulating that occasional transport is performed by means of a vehicle designed for the transport of more than 7 people, including the driver, remained in force. The newly adopted provision of art. 5e adds to this the prohibition of intermediation in ordering transport to drivers of vehicles structurally other than those specified above. Therefore, still a large number of entities are not admitted to the market. They provide transport services in a "gray zone" using the Uber or similar applications, and using cars registered most often for 4-5 people with a driver, even if they are entrepreneurs and have a license to transport people by car. Therefore, if the driver wants to use the services of intermediaries, he must adapt to the requirements,

\footnotetext{
${ }^{9}$ According to the new regulations, a financial penalty for an entrepreneur who intermediates in the transport of persons with violation of obligations or conditions of road transport, may be from 5,000 up to 40 thousand PLN for each violation (art. 92a (1)), but not more than 100,000 PLN in total (art. 92a (5)(5)).
} 
above all, own a vehicle with a registered number of seats from 7 to 9 and obtain a license suitable for him.

It is worth mentioning that occasional passenger car transport that does not meet the above criterion is possible, but on your own, without using an intermediary. This possibility is provided by art. $18(4 \mathrm{~b})$, provided that the vehicle is driven by the entrepreneur providing the transport service or the driver employed by him (a), based on a contract concluded in writing at the business premises (b), after determining the flat-rate fee before transport, regulated with or without cash on the company's premises (c). From 1 January 2020, the contract should be concluded directly with the client, each time before the commencement of the service of a given transport in written or electronic form ${ }^{10}$, at the premises of the enterprise being a real estate or part of a real estate.

Further, new provisions from art. $27 \mathrm{~b}(1)(1)$ obligate the intermediary to verify whether the entrepreneur wishing to accept orders for the carriage of persons actually holds it. In the alternative, it can also obtain information on the validity of this license from the granting authority. Information about this verification and its result must be made available at the request of the Road Transport Inspection authorities or the National Tax Administration within 21 days of receipt of the application (art. 27b (1)(4)). If the license of the driver has expired or if he has suspended his services, he should inform about it the intermediary forwarding the order to him in written or in electronic form, within 7 days from the date of loss of the license or from the date on which the suspension period began. In the absence of such information, the intermediary is not liable in the form of an obligation to pay a financial penalty, nor is he threatened to initiate the procedure of withdrawal of the operating license.

In order to fulfill the obligations set out in the Act, the intermediate must keep an electronic register of forwarded transport orders and electronic records of entrepreneurs commissioned to transport passengers. These data should be stored for a period of five years from the end of the calendar year in which the transport was ordered. They should also be made available at the request of Road Transport Inspection bodies or the National Tax Administration within 21 days of receipt of the application.

Burdening the intermediary of all of the above requirements, i.e. obtaining a license, conducting driver verification, keeping a register of orders and records of cooperating entrepreneurs, does not seem to be a particularly difficult barrier to overcome in seeking to exist on the market. This is likely to increase the operating costs that can be passed on to consumers of transport services. Although certainly some of these obligations, such as keeping registers and records, were already met due to the internal needs of the platforms. Nevertheless, these rules and the associated burdens are necessary, not only because of the need to ensure fair competition conditions on the market, but also for the safety of passenger transport.

\footnotetext{
${ }^{10}$ It is about submitting a declaration of intent in electronic form with a qualified electronic signature, as provided for in Article $78^{1}$ of the Polish Civil Code (Dz. U. 2019 poz. 1145).
} 
The customer can be sure that he is served by licensed entities, i.e. as authorized by the state and controlled by it. Drivers providing services are verified, licensed entrepreneurs with a specific scope of responsibility.

Finally, it is worth mentioning the liberalization of regulations conditioning access to the transport market. An entrepreneur applying for a passenger transport license for a car or 7-9 passenger vehicle does not need to have a certificate of professional competence. He also does not have to show financial security in the amount of 9,000 euro for the first vehicle and 5,000 euro for each next. This value was reduced to 5,000 PLN. The fees for the above licenses have also been reduced to the amount of the fee for a taxi license in Warsaw.

\section{Conclusion}

Business models that implement the idea of sharing economy are emerging and their further development can be expected. Their universality is growing and perhaps, as Sundararajan predicts (2016, p. 2), centralized corporate capitalism will transform into dispersed folk capitalism ${ }^{11}$. Although modern solutions are accepted, desirable, and they stimulate economic development, the example of Uber and similar platforms shows that when they reach a wellestablished market, existing players operating in a classic way for a given industry do not accept the existence of new competition. Especially when they think it is unfair, because it bypasses the requirements of legal provisions that must be met in a given field by a traditional service provider. There is also the legislator, which has the duty to weigh the interests of a given sector of the economy, with the general social interest associated with the development of innovative solutions. In other words, lawmakers have to decide on the direction of changes to the regulation: will it, as H. Schneider $(2017$, p. 6) writes, in typical way delay or stop innovation, or will it liberalize the rules to give all parties opportunities for market share.

The content of the road transport regulations that were in force until last year shows, that the activity of an intermediary in contacting drivers and passengers has not yet been provided for by the legal system. In terms of statutory requirements imposed on transport organizers, Uber did not have to meet any, because it presented itself only as a platform associating consumers with drivers, and not as an entity performing passenger transport. He did not verify the actual preparation and competence of these drivers to provide services. All responsibility rested on them, despite the obligations specified by law, they often did not meet them and they were punished for it.

\footnotetext{
${ }^{11}$ The concept was created in the 1950s in the USA, it also gained popularity in Western Europe. It proclaimed that capitalism should transform into a system in which property is spread among employees. Thanks to shares and bonds, they participate in the company's profits and have an impact on its management. Capital is dispersed and capitalists lose their economic advantage, thanks to which the main reason for the conflict between the capitalist and the employee disappears (Antoszewski, 2004, p. 154).
} 
The analysis of legal provisions carried out in this paper in the context of the activities of intermediary platforms such as Uber, show that:

- The amendment of the law did not change a lot in the situation of drivers - in order to act legally, they must adapt. They must act as legal and registered companies and therefore incur fiscal obligations to the state. They also have to meet formal obligations in relation to their qualifications (license) and technical requirements for their vehicles (registered number of seats). The new regulations should, however, increase the sense of justice and equal treatment of entrepreneurs due to the unification of the requirements for all entities providing passenger transport services. This should have a positive impact on fair competition.

- Uber must also adapt, as its activities have been classified as a transport service. Such a position may indeed prove to be common throughout the European Union due to the CJEU ruling in this respect. Uber himself is also willing to comply with the new rules. If an innovator adapts to regulation, he becomes more exposed to creative destruction from an even newer player, with an even more groundbreaking innovation (Schneider, 2017). In the light of clear legal rules and obligations, the status and activity of intermediary platforms is no longer in the sphere of legal uncertainty.

- The legislator decided to respect the prevailing trends and include innovation in regulations. However, he has dressed it with a number of requirements, which, combined with formal restrictions for drivers, will certainly affect the creative aspect of this business model. Innovation and technology, however desirable and practical for consumers, of course cannot function outside the law in today's world.

- Due to the regulation of the activities of intermediary platforms, and thus greater legal certainty and common standards that must be met, the potential increase in the quality of transport services for consumers should be expected. Price is a significant factor, but it should not be the only one when choosing a service provider for passenger transport.

\section{References}

1. Act of 18 July 2002 on the provision of electronic services, Dz.U. 2019, poz. 123.

2. Act of 20 June 1997 on road traffic, Dz.U. z 2019, poz. 2140.

3. Act of 23 April 1964 - Civil Code, Dz.U. 2019, poz. 1145.

4. Act of 6 September 2001 on road transport, Dz.U. 2019, poz. 58.

5. Antoszewski, A. (2004). Leksykon politologii. Warszawa: Atla 2. 
6. Belk, R. (2014). You are what you can access: Sharing and collaborative consumption online. Journal of Business Research, 67, pp. 1595-1600, doi: 10.1016/j.jbusres. 2013.10.001.

7. Botsman, R. (2015). Defining The Sharing Economy: What Is Collaborative Consumption - And What Isn't? Retrieved from https://www.fastcompany.com/ 3046119/defining-thesharing-economy-what-is-collaborative-consumption-and-what-isnt, 20.02.2020.

8. Burgiel, A. (2015). Wspólna konsumpcja jako alternatywny model spożycia i jej przejawy w zachowaniach konsumentów. In: E. Kieżel, and S. Smyczek (Eds.), Zachowania konsumentów. Procesy unowocześniania konsumpcji (pp. 153-192). Warszawa: Wolters Kluwer.

9. CJEU judgment from 20 December 2017, C-434/15, Asociación Profesional Elite Taxi v. Uber Systems Spain SL, OJ C 363, 3.11.2015.

10. Dickinson, G., 26.06.2018. How the world is going to war with Uber, The Telegraph. Retrieved from https://www.telegraph.co.uk/travel/news/where-is-uber-banned/, 20.02.2020.

11. Directive 2000/31/EC of the European Parliament and of the Council of 8 June 2000 on certain legal aspects of information society services, in particular electronic commerce, in the Internal Market, OJ L 178, 17.07.2000, p. 1-16.

12. Duszczenko, D., 15.03.2019. Dlaczego należy poprzeć strajk taksówkarzy, a Ubera odinstalować, Krytyka Polityczna. Retrieved from https://krytykapolityczna.pl/kraj/ dlaczego-nalezy-poprzec-strajk-taksowkarzy-a-ubera-odinstalowac/, 20.02.2020.

13. Duszczyk, M., 31.07.2018. Uber podgryza taxi coraz mocniej, Rzeczpospolita. Retrieved from https://www.rp.pl/Transport-drogowy/307309925-Uber-podgryza-taxi-corazmocniej.html, 15.06.2019.

14. European Parliament press releases, 15.06.2017. Sharing economy: Parliament calls for clear EU guidelines. Retrieved from http://www.europarl.europa.eu/news/en/pressroom/20170609IPR77014/sharing-economy-parliament-calls-for-clear-eu-guidelines, 20.02.2020.

15. Hamari, J., Sjöklint, M., and Ukkonen, A. (2015). The sharing economy: Why people participate in collaborative consumption. Journal of the Association for Information Science and Technology, 2047-2059, doi: 10.1002/asi.23552. Retrieved from SSRN: https://ssrn.com/abstract=2271971, 15.06.2019.

16. Kiwnik-Pargana, J., 15.06.2017. PE za jasnymi przepisami w sprawie ustug typu Uber czy Airbnb. Retrieved from https://www.pap.pl/aktualnosci/news,976126,pe-za-jasnymiprzepisami-w-sprawie-uslug-typu-uber-czy-airbnb.html, 20.02.2020.

17. Komisja Europejska, 2.06.2016. Europejski program na rzecz gospodarki dzielenia sie, $\operatorname{COM}(2016) \quad 356$, Retrieved from https://ec.europa.eu/docsroom/documents/ 16881/attachments/2/translations/pl/renditions/pdf, 20.02.2020. 
18. Pichère, P., 29.04.2016. Les artisans face au choc de l'ubérisation, "Le Moniteur". Retrieved from https://www.lemoniteur.fr/article/les-artisans-face-au-choc-de-1uberisation.1165484, 20.02.2020.

19. Regulation (EC) No $1073 / 2009$ of the European Parliament and of the Council of 21 October 2009 on common rules for access to the international market for coach and bus services, and amending Regulation (EC) No 561/2006, OJ L 300, 14.11.2009, 88-105.

20. Regulation of the Minister of Infrastructure of 31 December 2002 on the technical conditions of vehicles and the scope of their necessary equipment, Dz.U. $2003 \mathrm{nr} \mathrm{32,}$ poz. 262.

21. Rhodes, A., 22.09.2017. Uber: which countries have banned the controversial taxi app, "Independent". Retrieved from https://www.independent.co.uk/travel/news-andadvice/uber-ban-countries-where-world-taxi-app-europe-taxi-us-states-china-asia-legala7707436.html, 20.02.2020.

22. Rozwadowska, A., 20.12.2017. Taksówkarze kontra Uber. Co po wyroku TSUE? Jak zmieni sie prawo? Wyborcza.pl. Retrieved from http://wyborcza.pl/7, 155287,22812359,taksowkarze-kontra-uber-co-po-wyroku-tsue-jak-zmieni-sieprawo.html, 20.02.2020.

23. Rudnicka, E., Czym jest sharing economy i jak zmienia biznesowy krajobraz? Harvard Business Review Polska. Retrieved from https://www.hbrp.pl/b/czym-jest-sharingeconomy-i-jak-zmienia-biznesowy-krajobraz/YKrUu6Qu, 20.02.2020.

24. Ruling of the Voivodship Administrative Court in Łódź from 15 May 2018, III SA/Ld 686/17.

25. Ruling of the Voivodship Administrative Court in Olsztyn from 6 February 2018, II SA/O1 977/17.

26. Schneider, H. (2017). Creative Destruction and the Sharing Economy: Uber as Disruptive Innovation. Cheltenhan: Edward Elgar Publishing.

27. Schor, J. (2014). Debating the Sharing Economy. Great Transition Initiative (October 2014). Retrieved from http://www.greattransition.org/publication/debating-the-sharingeconomy, 20.02.2020.

28. Słowik, P., Styczyński, J., 30.08.2016. Coraz trudniejszy żywot Ubera nad Wisłą. Gazeta Prawna. Retrieved from https://serwisy.gazetaprawna.pl/transport/artykuly/971411, coraz-trudniejszy-zywot-ubera-nad-wisla.html, 20.02.2020

29. Stalmach, S., 29.08.2014. Odpłatny przewóz osób bez licencji surowo karany, Rzeczpospolita. Retrieved from https://www.rp.pl/artykul/1136556-Odplatny-przewozosob-bez-licencji-surowo-karany.html, 20.02.2020.

30. Stępnicka, N. (2018). Globalny, glokalny czy grobalny? - przypadek Uber Technologies, Inc. Zeszyty Naukowe Politechniki Śląskiej, Organizacja i Zarządzanie, 123, 489-499, doi: 10.29119/1641-3466.2018.123.33. 
31. Sundararajan, A. (2016). The Sharing Economy: The End of Employment and the Rise of Crowd-Based Capitalism. Cambridge: MIT Press.

32. Szanduła, W., 15.01.2017. Kierowca Ubera winny świadczenia usługi przewozowej osób bez wymaganej licencji. Gazeta Prawna. Retrieved from https://serwisy.gazetaprawna.pl/ transport/artykuly/1010674,przelomowy-wyrok-wobec-kierowcy-ubera.html, 20.02.2020.

33. Toroń, M., Wiese, K. (2017). Aplikacja UBER lub jak ująć sharing economy w istniejące ramy prawne? Internetowy Kwartalnik Antymonopolowy i Regulacyjny, 5(6), 8-27, doi: 10.7172/2299-5749.IKAR.5.6.1.

34. Uber (2019). Podstawowe informacje. Retrieved from https://www.uber.com/pl/drive/ requirements/, 20.02.2020.

35. UOKiK, 5.05.2016. Uber - stanowisko UOKiK. Retrieved from https://www.uokik.gov.pl/ aktualnosci.php?news_id=12352, 20.02.2020. 